\title{
Effect of petroleum-derived substances on life history traits of black bean aphid (Aphis fabae Scop.) and on the growth and chemical composition of broad bean
}

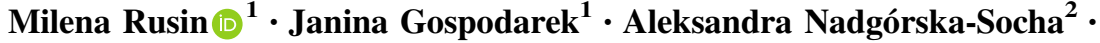 \\ Gabriela Barczyk ${ }^{2}$
}

Accepted: 12 January 2017 / Published online: 31 January 2017

(C) The Author(s) 2016; This article is published with open access at Springerlink.com

\begin{abstract}
The aim of the study was to determine the effects of various petroleum-derived substances, namely petrol, diesel fuel and spent engine oil, on life history traits and population dynamics of the black bean aphid Aphis fabae Scop. and on growth and chemical composition of its host plant Vicia faba L. Each substance was tested separately, using two concentrations $\left(9 \mathrm{~g} \mathrm{~kg}^{-1}\right.$ and $\left.18 \mathrm{~g} \mathrm{~kg}^{-1}\right)$. The experiment was conducted in four replications (four pots with five plants in each pot per treatment). Plants were cultivated in both control and contaminated soils. After six weeks from soil contamination and five weeks from sowing the seeds, observations of the effect of petroleum-derived substances on traits of three successive generations of aphids were conducted. Aphids were inoculated separately on leaves using cylindrical cages hermetically closed on both sides. Contamination of aphid occurred through its host plant. Results showed that all tested substances adversely affected $A$. fabae life history traits and population dynamics: extension of the prereproductive period, reduction of fecundity and life span, reduction of the population intrinsic growth rate. In broad bean, leaf, roots, and shoot growth was also impaired in most conditions, whereas nutrient and heavy metal content varied according to
\end{abstract}

Electronic supplementary material The online version of this article (doi:10.1007/s10646-017-1764-9) contains supplementary material, which is available to authorized users.

Milena Rusin

milena_rusin@wp.pl

1 Department of Agricultural Environment Protection, University of Agriculture, al. A. Mickiewicza 21, Krakow 31-120, Poland

2 Department of Ecology, University of Silesia, Bankowa 9, Katowice 40-007, Poland substances, their concentration, as well as plant part analysed. Results indicate that soil contamination with petroleum-derived substances entails far-reaching changes not only in organisms directly exposed to these pollutants (plants), but also indirectly in herbivores (aphids) and consequently provides information about potential negative effects on further links of the food chain, i.e., for predators and parasitoids.

Keywords Petroleum-derived Substances - Aphis fabae Scop. Heavy metals $\cdot$ Macronutrients $\cdot$ Micronutrients $\cdot$ Broad bean

\section{Introduction}

Due to their commonness and versatility, petroleum and petroleum-derived substances (PDSs) are used in many industrial fields. However, once they pervade the natural environment, these compounds can adversely affect the growth and development of cultivated plants (Shirdam et al. 2008; Gbadebo and Adenuga 2012). They contribute to the increase of heavy metal content in plants (Onweremadu and Duruigbo 2007; Ujowundu et al. 2011; Rusin et al. 2015), they reduce chlorophyll, protein and carotenoid levels (Achuba 2006; Adenipekun et al. 2008), they constrain plant germination, decrease photosynthetic activity (Agbogidi and Eshegbeyi 2006; Besalatpour et al. 2008; Njoku et al. 2008), and modify the content of micro- and macroelements in plants (Odjegba and Atebe 2007; Shukry et al. 2013). The effect of PDSs on nutrient levels depends chiefly on the type and dose of compounds applied as well as plant 
species (Wyszkowski and Wyszkowska 2005; Wyszkowski and Ziółkowska 2009a).

Additionally, PDSs modify physicochemical and biological properties of soil, which may also indirectly affect the condition and health status of cultivated plants (Wyszkowska et al. 2002; Lawrence 2013). These substances cause far-reaching changes in the amount and composition of organic content, a reduction of water holding capacity, an increase in the demand for oxygen; they hamper or completely block air transport between the atmosphere and the soil (Caravaca and Rodán 2003; Iturbe et al. 2007), as well as modify the abundance and species composition of edaphic microflora and fauna (Baran et al. 2004). Soil contamination with petroleum causes the sorption complex capacity to drop and reduces the ability to exchange calcium, magnesium, and potassium while also decreasing the availability of these macrocomponents (Agbogidi et al. 2007; Wyszkowski and Ziółkowska 2008). Cultivated plants show varying degrees of susceptibility to the presence of PDSs in soil, the resultant harmful impact depending on numerous factors, such as: type and dose of substances applied, soil properties, soil moisture and $\mathrm{pH}$, oxygen and organic matter content, fertilisation applied and plant species (Wyszkowski and Ziółkowska 2009a).

While the impact of PDSs on plant growth and other organisms directly exposed to the contact with pollutants (e.g., edaphic or aquatic invertebrates) is well documented in scientific literature, information concerning the indirect impact of these compounds from soil via plant on herbivores is still lacking. Arthropods, given their enormous diversity, easy acquisition and breeding, high fecundity rate and short life cycle, are a useful element to consider in a comprehensive assessment of the impact of pollutants on successive trophic chain links. Among these organisms, aphids are highly sensitive to all changes in their food, which quickly occur in their life cycle traits (Harrington and Stork 1995). The changes in biology ensuing from the activity of xenobiotics may, in turn, disturb the synchronisation and occurrence of herbivores and their natural enemies, thus exerting harmful effects on plant production (Percy et al. 2002).

Broad bean (Vicia faba L.) is a particularly useful testing plant, both as a bioindicator of oil pollution (Malallah et al. 1996) and for detecting mutagenic substances (Grant et al. 1992, Kanaya et al. 1994), and also due to the fact that aphid life cycle is very fast on this host plant, and hence the impact of the experimental factor can be easily observed.

The soil-plant-herbivore model has been used to date when assessing the environmental impact of pollutants mostly with regard to heavy metals (Merrington et al. 1997a, b, Winder et al. 1999, Green et al. 2006, Kafel et al. 2010) and herbicides (Lipok 2009). In our research, we applied it to determine the effect of PDSs.
The aim of the conducted study was to establish the effect of different concentrations of PDSs, namely, petrol, diesel fuel and spent engine oil on life cycle traits of aphids A. fabae feeding on broad beans and on the growth and chemical composition of the host plant.

\section{Materials and methods}

\section{Experimental setup}

The experiment was performed in 2014 in pots that could hold $3.8 \mathrm{~kg}$ of soil dry mass. In late April 2014, soil (loamy-sand, $\mathrm{pH}$ in $\mathrm{KCl}=6.12, \mathrm{pH}$ in $\mathrm{H}_{2} \mathrm{O}=6.98$, water-holding capacity $=29.5 \%$, total organic $\mathrm{C}=0.97 \%$, $\mathrm{N}$ content $=0.09 \%$, available $\mathrm{K}$ content $=13.00 \mathrm{mg}$ $\mathrm{K}_{2} \mathrm{O} 100 \mathrm{~g}^{-1}$, available $\mathrm{P}$ content $=11.85 \mathrm{mg} \mathrm{P}_{2} \mathrm{O}_{5} 100 \mathrm{~g}^{-1}$, $\mathrm{Pb}$ content $=25.5 \mathrm{mg} \mathrm{kg}^{-1}, \mathrm{Cd}$ content $=0.99 \mathrm{mg} \mathrm{kg}^{-1}, \mathrm{Ni}$ content $=2.19 \mathrm{mg} \mathrm{kg}^{-1}, \mathrm{Zn} \quad$ content $=51.7 \mathrm{mg} \mathrm{kg}^{-1}, \mathrm{Cu}$ content $=5.02 \mathrm{mg} \mathrm{kg}^{-1}$, cation exchange capacity: $\mathrm{Ca}=$ $3.71 \mathrm{cmol} \mathrm{kg}^{-1}, \mathrm{Mg}=0.37 \mathrm{cmol} \mathrm{kg}^{-1}, \mathrm{~K}=0.33 \mathrm{cmol} \mathrm{kg}^{-1}$, $\mathrm{Na}=0.01 \mathrm{cmol} \mathrm{kg}^{-1}$ ) was collected from uncultivated areas from level $0-20 \mathrm{~cm}$, finely ground and subsequently spread to form a thin layer on a foil mat. Prior to contamination with PDSs, basal fertilization was applied by treating the soil with $0.27 \mathrm{~g} \mathrm{~N}$ (in form of $\mathrm{NH}_{4} \mathrm{NO}_{3}$ ), $0.14 \mathrm{~g} \mathrm{P}$ (in form of $\mathrm{KH}_{2} \mathrm{PO}_{4}$ ) and $0.21 \mathrm{~g} \mathrm{~K}$ (in form of $\mathrm{KCl}$ ) per pot. After thoroughly mixing the soil, it was contaminated with engine oil, diesel fuel and petrol at two doses: dose I- $9 \mathrm{~g}$ of PDS per $\mathrm{kg}$ of soil dry mass, dose II- $18 \mathrm{~g}$ of PDS per $\mathrm{kg}$ of soil dry mass. Petrol and diesel fuel came from BP petrol station whereas engine oil from Orlen petrol station. Petrol (BP Unleaded 95) is a complex mixture of volatile hydrocarbons containing paraffins, naphthenes, olefins and aromatic hydrocarbons which contain between $\mathrm{C} 4$ and $\mathrm{C} 12$ atoms in the molecule (detailed description of the ingredients in Material Safety Data Sheet: http://www.bp. com/content/dam/bp-plus/pl_pl/downloads/PDF/SDS\%20 benzyna\%2095.pdf). Diesel fuel (BP Diesel Fuel) is a mixture of hydrocarbons middle distillates, made between C10 and C28 atoms and may also contain fatty acid methyl ester (FAME) (detailed description in Material Safety Data Sheet: http://www.bp.com/content/dam/bp-plus/pl_pl/ downloads/PDF/SDS\%20Dieselpdf.pdf). Engine oil (PLATINUM Classic Semisynthetic 10W-40) is a mixture of mineral and synthetic base oils, enriching additives (detailed description in Material Safety Data Sheet: http://www. orlenoil.pl/_layouts/OrlenOilDownload/Download.ashx? downloadUrl=/PL/NaszaOferta/KartyCharakterystyki/Karty Charakterystyki/1117.pdf?) and it was used for one year (in a petrol engine) prior to application in this experiment. Heavy metals content is not mentioned in material safety data sheets of these substances. In order to evenly distribute 
the contaminants, the predetermined amount of each PDS was poured onto a thinly spread layer of soil on a foil mat using a laboratory pipette. The soil was then thoroughly mixed several times and placed in pots. The area of pot was $706.5 \mathrm{~cm}^{2}$ (30 $\mathrm{cm}$ in diameter). The pots were arranged so that the distance between them (i.e., external edges) was 50 $\mathrm{cm}$ to avoid competition. The non-contaminated soil was placed in identical pots and constituted the control treatment. After one week, broad bean (Vicia faba L.) seeds, 'Bartek' cultivar, were sown in each pot at an amount of seven seeds per pot. After sprouting, the plants were thinned out and five plants were left in each pot to avoid the competition between germinated seedlings. The distance between plants in each pot obtained in this way amounted approx. $10 \mathrm{~cm}$, corresponding to a standard seed density for this plant under field condition. The pot experiment was performed in quadruplicate.

\section{Black bean aphid (Aphis fabae Scop.) traits and population dynamics}

Aphids were inoculated on six week-old plants $(30 \mathrm{~cm}$ height), using cylindrical cages $(12 \mathrm{~cm}$ diameter $\times 20 \mathrm{~cm}$ height) made of closely woven airy fabric placed on broad bean leaves (at the same level on each plant to avoid leaf age influence on the pest biology). One cage covered within only one, whole single broad bean leaf used for investigating the life history traits of a single aphid female. The cages were attached to the leaves and hermetically closed on both sides in order to avoid the escape of aphids. The investigations were conducted on A. fabae individuals from the own culture of the Agricultural Environment Protection Department maintained on the same host plant, i.e., broad bean, Bartek c.v. Three wingless aphid females were placed in each cage and removed completely once they gave birth to the first larvae. One larva was left in each cage. After it reached sexual maturity, its fecundity was determined every day, while newborn larvae were removed each time except the first one, which was transferred immediately to new cage in order to determine the demographic indicators of subsequent generation. Two cages were placed on each test plant to investigate the life history of the first generation ( 40 cages in total for treatment) to ensure the right final number of females to study the aphid life history of A. fabae. This procedure was applied because some females initially placed on the host plant (using a brush) died before giving birth to the larvae. Cages used to monitor the second and third generation were placed on the subsequent branches of broad bean plants, adopting the rule that it should always be on leaves from the same foliage level of the plant in each treatment and generation analysed. Aphid life span and fecundity were assessed for 25 females of each generation and treatment. The population intrinsic growth rate was calculated using the formula developed by Wyatt and White (1977):

$$
r_{m}=\frac{\left(0.738 \cdot \ln M_{d}\right)}{d}
$$

where:

$r_{m} \quad$ is the population intrinsic growth rate,

$d \quad$ is the duration of pre-reproductive period (from birth to producing the first offspring),

$M_{d} \quad$ is the mean number of larvae born in the period from $d$ to $2 d$ days from birth.

The constant value of 0.738 is an approximation of the proportion of the total fecundity produced by a female in the period from $d$ to $2 d$ days from birth.

A. fabae is a host-alternating species. Viviparous spring winged or wingless female aphid hatch from diapausing eggs on the primary host. Their winged parthenogenetic descendants disperse to different herbaceous secondary host plants, where numerous parthenogenetic generations take place throughout the growing season. In autumn, decreasing day lengths and temperatures induce the sexual phase of the life cycle. Then winged morphs migrate back to primary hosts, where give birth to sexual females, which mate with the males and deposit overwintering eggs (Sandrock et al. 2011). In our experiment only asexual reproduction of $A$. fabae was investigated.

\section{Growth of broad bean plants}

After the experiment was finished, plants were harvested from the pots and their growth was evaluated in laboratory conditions (total length and mass of shoots, number and mass of leaves, length and mass of roots).

\section{Chemical composition of plants}

In order to determine the nutrients (calcium, potassium, iron, magnesium) and heavy metal (copper, manganese, nickel, lead, zinc, cadmium) concentrations in plants parts, plant material was cleaned of any patches of deposited aphid honeydew and other surface contaminants, washed in tap, next in distilled water. It was then dried at $105^{\circ} \mathrm{C}$ for $48 \mathrm{~h}$. A portion of $0.25 \mathrm{~g}$ dried plant material was digested with $5 \mathrm{ml}$ of $\mathrm{HNO}_{3}$ at $110{ }^{\circ} \mathrm{C}$ and then diluted to $10 \mathrm{~mL}$ with deionized water. Next, the metal content was measured using flame absorption spectrometry (Unicam 939 Solar) (Azcue and Murdoch 1994; Nadgórska-Socha et al. 2013). The quality of the analytical procedure was checked using a reference material (Certified Reference Material CTA-OTL1 Oriental Tobacco Leaves) with the same quantities of samples. Carbon, nitrogen and sulphur contents were 
Fig. 1 The effect of petroleumderived substances on mean life span of Aphis fabae Scop. (days). $C$ control soil, $P$ soil contaminated with petrol, $E O$ soil contaminated with engine oil, $D F$ soil contaminated with diesel fuel, $I, I I$ doses of pollutants. Values marked by different letters for each generation are statistically different $(p<0.05)$



determined in a Variomax CNS analyzer. Due to the small amount of plant material obtained for chemical analyses, no assays for nitrogen, carbon and sulphur levels were conducted on plant roots from samples contaminated with diesel fuel at both doses and with petrol at the dose of $18 \mathrm{~g}$ $\mathrm{kg}^{-1}$. The following indicators were calculated: $\mathrm{K} /(\mathrm{Ca}$ $+\mathrm{Mg}$ ), $\mathrm{Ca} / \mathrm{Mg}, \mathrm{N} / \mathrm{S}$, representing ratios between selected nutrients in plants.

\section{Statistical analysis}

The obtained results were analyzed, checked for normality (Shapiro-Wilk test with Lilliefors correction) and equality of variance (Levene's test) and when necessary the data were $\log$ transformed. The significance of differences between the means were tested by one-factor variance analysis (STATISTICA 10.0 software), and the means were differentiated by Fisher's LSD test at $p<0.05$.

Multiple regression equations were derived to determine which of the PDSs dose, accumulated heavy metal and nutrient contents influenced aphid traits. The method of stepwise forward regression was applied. The equations concerned the relationships between life span, fecundity as well as intrinsic growth rate and the examined of PDSs dose $\left(9 \mathrm{~g} \mathrm{~kg}^{-1}\right.$ and $18 \mathrm{~g} \mathrm{~kg}^{-1}$ respectively), accumulated nutrients (calcium, potassium, iron, magnesium) and heavy metals: copper, manganese, nickel, lead, zinc, cadmium. Significance of differences was set at a level of $p<0.05$. Moreover, the value of the linear correlation coefficient between fecundity and life span was calculated.

CANOCO 4.5 was used to carry out Principal Component Analysis (PCA) (Ter Braak and Šmilauer 2002). Principal Component Analysis assessed the relationships between plant composition and PDS contamination.

\section{Results}

\section{Life cycle traits of black bean aphid (Aphis fabae Scop.)}

All PDSs, at both doses used, caused a significant life span reduction in the three generations of A. fabae that feed on plants growing in contaminated soil relative to control conditions (by approx. 30\%) (Fig. 1). As the content of xenobiotics in the soil increased, most frequently the black bean aphid life span declined. Moreover aphid life span decreased over time in subsequently emerging generations of the pest under all conditions (including control). All PDSs resulted in a significant drop of fecundity in all generations of A. fabae females, at both doses applied (Fig. 2). The most adverse effect on this parameter was exerted by engine oil and diesel fuel at the dose of $18 \mathrm{~g} \mathrm{~kg}^{-1}$, which caused female fecundity in the first and second generation to decrease by over $90 \%$ and completely prevented the birth of new larvae in the third generation. As in the previous case analysed, aphid fecundity increasingly declined in subsequent generations. The duration of pre-reproductive period $(d)$ of $A$. fabae ranged from 9.3 to 12.0 days for the first generation, from 9.0 to 11.9 days for the second one and from 11.3 to 12.8 for the third one (Table 1). Both doses of engine oil, as well as 18 $\mathrm{g} \mathrm{kg}^{-1}$ of diesel fuel caused the process of birthing larvae to cease completely in the third generation of females. All PDSs applied at both doses (except the lower dose of engine oil) resulted in a significant elongation of the prereproductive period in the first two generations of females. $M_{d}$ in all generations was the largest in the controls (Table 1). In aphids living on plants contaminated by engine oil and diesel fuel, females in all generations gave birth to significantly fewer larvae vs. control during the evaluated period $\left(M_{d}\right)$. Petrol at the dose of $9 \mathrm{~g} \mathrm{~kg}^{-1}$ led to a 
Fig. 2 The effect of petroleumderived substances on mean fecundity of Aphis fabae Scop. (No. of larvae per one female). Symbols as in Fig. 1. Values marked by different letters for each generation are statistically different $(p<0.05)$

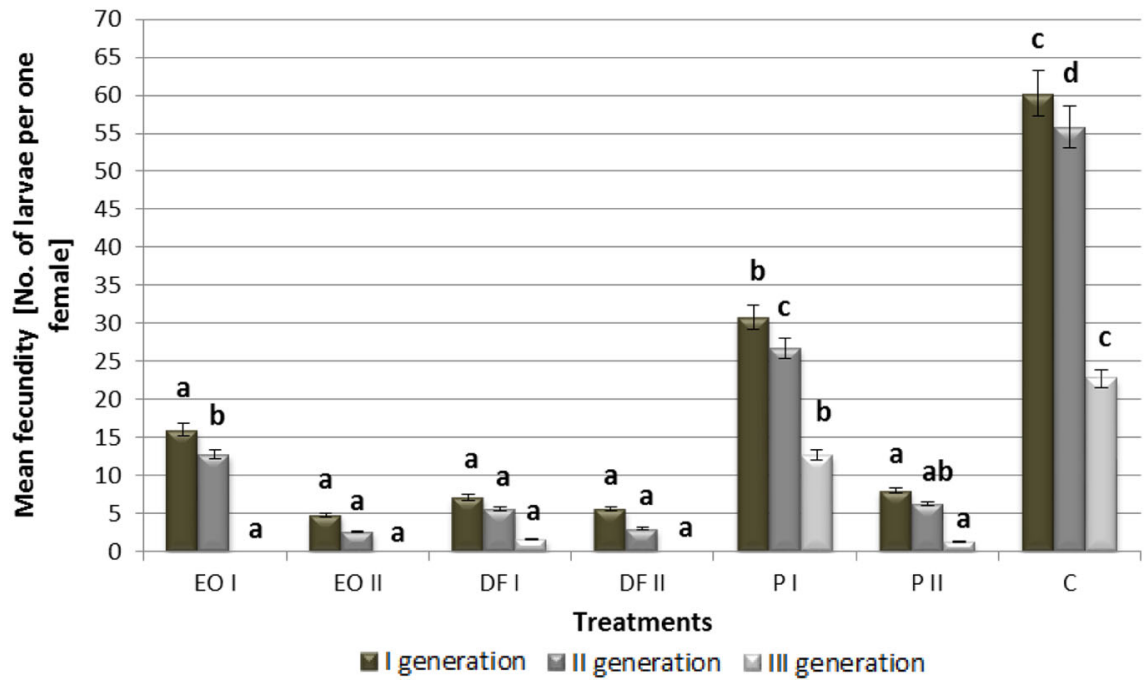

Table 1 The effect of petroleum-derived substances on some biological parameters

\begin{tabular}{llllllll}
\hline Details & \multicolumn{1}{l}{$d$} & \multicolumn{5}{l}{$M_{d}$} \\
\cline { 2 - 4 } \cline { 7 - 8 } Generation & I & II & III & & I & II & III \\
\hline EO I & $10.0^{\mathrm{ab} *}$ & $10.8^{\mathrm{ab}}$ & - & $9.3^{\mathrm{ab}}$ & $4.1^{\mathrm{ab}}$ & $0^{\mathrm{a}}$ \\
EO II & $10.8^{\mathrm{bc}}$ & $11.1^{\mathrm{b}}$ & - & $3.4^{\mathrm{a}}$ & $1.7^{\mathrm{a}}$ & $0^{\mathrm{a}}$ \\
DF I & $12.0^{\mathrm{c}}$ & $11.9^{\mathrm{c}}$ & $12.8^{\mathrm{b}}$ & $13.1^{\mathrm{b}}$ & $6.5^{\mathrm{ab}}$ & $1.0^{\mathrm{a}}$ \\
DF II & $11.3^{\mathrm{bc}}$ & $11.7^{\mathrm{bc}}$ & - & $5.4^{\mathrm{a}}$ & $2.3^{\mathrm{a}}$ & $0^{\mathrm{a}}$ \\
P I & $10.8^{\mathrm{bc}}$ & $10.3^{\mathrm{ab}}$ & $11.5^{\mathrm{a}}$ & $18.8^{\mathrm{bc}}$ & $9.7^{\mathrm{abc}}$ & $5.2^{\mathrm{b}}$ \\
P II & $11.5^{\mathrm{c}}$ & $11.7^{\mathrm{bc}}$ & $12.2^{\mathrm{ab}}$ & $7.6^{\mathrm{ab}}$ & $11.2^{\mathrm{bc}}$ & $4.1^{\mathrm{b}}$ \\
C & $9.3^{\mathrm{a}}$ & $9.0^{\mathrm{a}}$ & $11.3^{\mathrm{a}}$ & $27.8^{\mathrm{c}}$ & $12.2^{\mathrm{c}}$ & $10.8^{\mathrm{c}}$ \\
\hline
\end{tabular}

$d$ duration of pre-reproductive period, $M_{d}$ mean number of larvae born in time $=\mathrm{d}$ of Aphis fabae Scop

*Means in columns marked with the same letters do not differ significantly according to LSD test at $p<0.05$. Symbols as in Fig. 1

significant decrease in $M_{d}$ in the third generation of aphids, while the dose of $18 \mathrm{~g} \mathrm{~kg}^{-1}$ produced this effect both in the first and third generation. The population intrinsic growth rate reached the highest values in the first generation of the pest and dwindled in next generations, being reduced to zero under engine oil and diesel fuel contamination (Fig. 3). In the first generation, only the higher doses of PDSs $\left(18 \mathrm{~g} \mathrm{~kg}^{-1}\right)$ induced a significant drop in the population intrinsic growth rate relative to the control. However, both engine oil at the two doses and diesel fuel at the higher dose caused the studied parameter to fall significantly in the second generation. A significant reduction of the analysed parameter in the third generation was observed in females that feed on plants growing in the soil treated with engine oil and diesel fuel, both at the dose of $9 \mathrm{~g} \mathrm{~kg}^{-1}$ and $18 \mathrm{gkg}^{-1}$.

\section{Growth of broad bean plants}

All PDSs applied (except petrol at the dose of $9 \mathrm{~g} \mathrm{~kg}^{-1}$ ) had a negative impact on the growth of broad bean plants, significantly reducing the length and mass of shoots and roots, as well as the number and mass of leaves (Table 2). However, $9 \mathrm{~g} \mathrm{~kg}^{-1}$ of petrol caused a significant decrease in root length and mass. The growing dose of each xenobiotic was usually mirrored by the increasingly harmful effect on the growth of plant.

\section{Plant components and heavy metal content}

The impact of PDSs on the mineral nutrient content in plants was varied and depended on the analysed component, the dose and type of contaminant, as well as plant part. All PDSs caused a significant rise in the sulphur content in broad bean leaves and shoots, and usually also a rise in carbon content in these organs. Engine oil caused nitrogen content in plant leaves to lower significantly, decreasing also calcium content in leaves and shoots. Both applied doses of diesel fuel resulted in a significant decrease in potassium and nitrogen content in the leaves. On the other hand, they induced an increase in magnesium content in the leaves and shoots of the plants. Petrol led to an elevated level of nitrogen in broad bean leaves and shoots but also reduced level of calcium in these organs. Detailed data are provided in Supplemental Tables S1 and S2.

All PDSs most frequently caused a significant decrease in the computed values of $\mathrm{Ca} / \mathrm{Mg}$ and $\mathrm{N} / \mathrm{S}$ ratios in plant leaves and shoots (Table 3). Engine oil at both doses and diesel fuel at $9 \mathrm{~g} \mathrm{~kg}^{-1}$ induced an increase in $\mathrm{Ca} / \mathrm{Mg}$ ratio in plant roots. Diesel fuel significantly decreased $\mathrm{K} /(\mathrm{Ca}+\mathrm{Mg})$ ratio in all plant organs analysed. Both doses of engine oil 
Fig. 3 The effect of petroleumderived substances on population intrinsic growth rate $\left(r_{m}\right)$ of Aphis fabae Scop. Symbols as in Fig. 1. Values marked by different letters for each generation are statistically different $(p<0.05)$
Table 2 The effect of petroleum-derived substances on the growth of Vicia faba $\mathrm{L}$

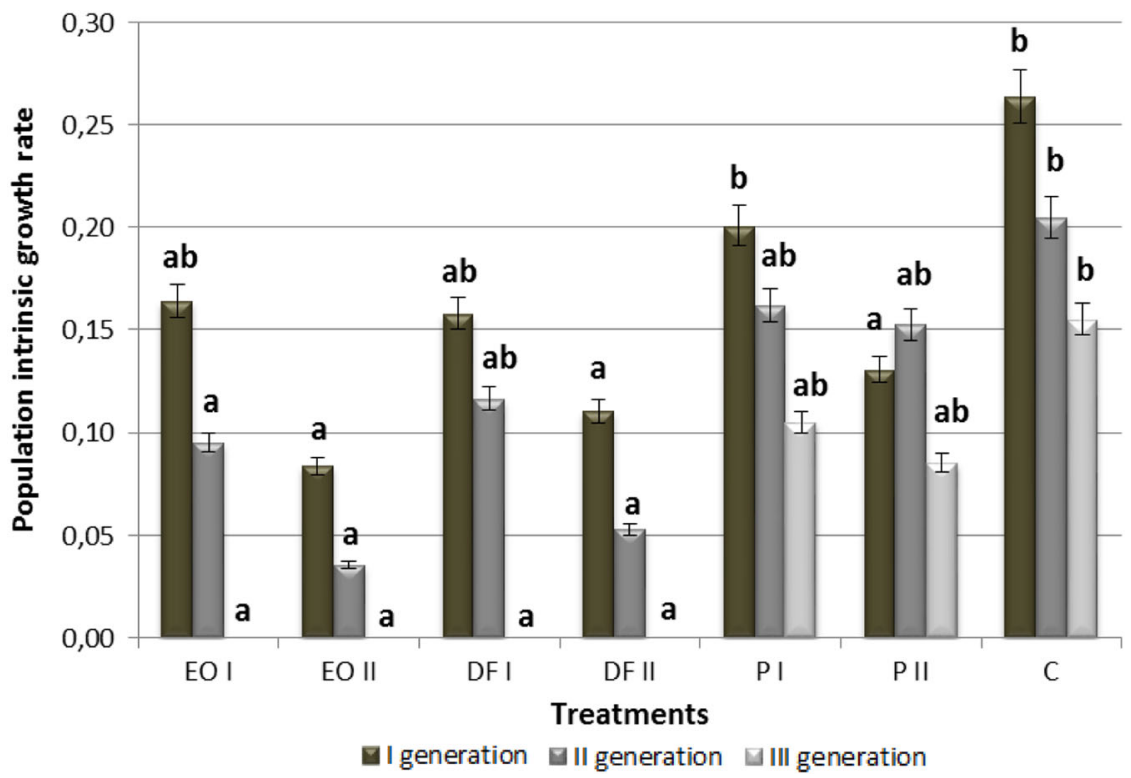

\begin{tabular}{llclllc}
\hline Details & $\begin{array}{l}\text { Sum of shoots } \\
\text { length per plant } \\
(\mathrm{cm})\end{array}$ & $\begin{array}{l}\text { Mass of } \\
\text { shoots per } \\
\text { plant }(\mathrm{g})\end{array}$ & $\begin{array}{l}\text { Number of } \\
\text { leaves per plant } \\
(\text { pcs. })\end{array}$ & $\begin{array}{l}\text { Mass of } \\
\text { leaves per } \\
\text { plant }(\mathrm{g})\end{array}$ & $\begin{array}{l}\text { Root length } \\
\text { per plant } \\
(\mathrm{cm})\end{array}$ & $\begin{array}{l}\text { Mass of root } \\
\text { per plant }(\mathrm{g})\end{array}$ \\
\hline EO I & $31.07^{\mathrm{a}^{*}}$ & $11.94^{\mathrm{a}}$ & $31.93^{\mathrm{b}}$ & $13.71^{\mathrm{b}}$ & $3.87^{\mathrm{a}}$ & $6.0^{\mathrm{a}}$ \\
EO II & $25.13^{\mathrm{a}}$ & $9.12^{\mathrm{a}}$ & $22.13^{\mathrm{a}}$ & $9.35^{\mathrm{a}}$ & $3.63^{\mathrm{a}}$ & $5.53^{\mathrm{a}}$ \\
DF I & $28.36^{\mathrm{a}}$ & $11.60^{\mathrm{a}}$ & $28.18^{\mathrm{ab}}$ & $11.41^{\mathrm{ab}}$ & $3.14^{\mathrm{a}}$ & $4.85^{\mathrm{a}}$ \\
DF II & $25.88^{\mathrm{a}}$ & $9.94^{\mathrm{a}}$ & $23.75^{\mathrm{ab}}$ & $10.02^{\mathrm{ab}}$ & $3.38^{\mathrm{a}}$ & $5.18^{\mathrm{a}}$ \\
P I & $48.13^{\mathrm{b}}$ & $18.75^{\mathrm{b}}$ & $56.93^{\mathrm{c}}$ & $24.54^{\mathrm{c}}$ & $7.60^{\mathrm{b}}$ & $12.06^{\mathrm{b}}$ \\
P II & $25.22^{\mathrm{a}}$ & $9.72^{\mathrm{a}}$ & $19.11^{\mathrm{a}}$ & $8.24^{\mathrm{a}}$ & $4.22^{\mathrm{a}}$ & $6.54^{\mathrm{a}}$ \\
C & $55.33^{\mathrm{b}}$ & $21.63^{\mathrm{b}}$ & $64.13^{\mathrm{c}}$ & $27.68^{\mathrm{c}}$ & $10.00^{\mathrm{c}}$ & $15.88^{\mathrm{c}}$ \\
\hline
\end{tabular}

*Means in columns marked with the same letters do not differ significantly according to LSD test at $p<0.05$. Symbols as in Fig. 1 augmented $\mathrm{K} /(\mathrm{Ca}+\mathrm{Mg})$ ratio in broad bean leaves while reducing it in roots. The lower dose of this contaminant also caused this indicator to rise in plant shoots. Petrol increased $\mathrm{K} /(\mathrm{Ca}+\mathrm{Mg})$ ratio in plant roots, whereas the dose of $18 \mathrm{~g}$ $\mathrm{kg}^{-1}$ additionally increased this indicator in plant leaves while reducing it in shoots.

As was the case with macrocomponents, the content of heavy metals in plants resulting from the presence of PDSs in soil was diverse (Table 4). All substances caused zinc and cadmium levels in plant leaves and roots as well as nickel level in shoots to drop. Both doses of engine oil also triggered a fall in the manganese content of broad bean leaves and shoots. However, they increased copper content in plant roots. Diesel fuel generated an increase in manganese level in broad bean leaves and shoots and a decrease in nickel level in roots. The diesel fuel dose of $9 \mathrm{~g} \mathrm{~kg}^{-1}$ caused an elevated lead content in leaves and increased root levels of copper and manganese. Both doses of petrol decreased shoot and leaf levels of manganese, whereas they increased shoot levels of lead.

\section{Relationships between black bean aphid traits, soil contamination with PDSs and broad bean chemical composition}

Multiple regression revealed that PDSs and $\mathrm{Zn}$ had a negative effect on life span of aphids (Table 5). PDSs and S and $\mathrm{Mn}$ content had a negative effect on fecundity and intrinsic growth rate ( $\mathrm{S}$ and $\mathrm{Mn}$ only for fecundity). Cadmium (for both above mentioned traits) and $\mathrm{N}, \mathrm{K}$ and $\mathrm{Ca}$ (for intrinsic growth rate) had a positive effect. Fecundity of aphids was strongly correlated with its life span (the correlation value amounted 0.892 ). 
Table 3 The effect of petroleum-derived substances on the ratio of nutrients in Vicia faba $\mathrm{L}$

\begin{tabular}{|c|c|c|c|}
\hline Details & $\mathrm{K} /(\mathrm{Ca}+\mathrm{Mg})$ & $\mathrm{Ca} / \mathrm{Mg}$ & $\mathrm{N} / \mathrm{S}$ \\
\hline \multicolumn{4}{|l|}{ Leaves } \\
\hline EO I & $1.66^{\mathrm{de} *}$ & $4.78^{\mathrm{b}}$ & $13.60^{\mathrm{b}}$ \\
\hline EO II & $1.75^{\mathrm{e}}$ & $3.67^{\mathrm{a}}$ & $12.41^{\mathrm{a}}$ \\
\hline DF I & $0.67^{\mathrm{a}}$ & $5.81^{\mathrm{c}}$ & $12.19^{\mathrm{a}}$ \\
\hline DF II & $0.86^{\mathrm{a}}$ & $6.33^{\mathrm{cd}}$ & $13.51^{\mathrm{b}}$ \\
\hline P I & $1.27^{\mathrm{bc}}$ & $7.27^{\mathrm{de}}$ & $16.91^{\mathrm{d}}$ \\
\hline P II & $1.48^{\mathrm{cd}}$ & $4.52^{\mathrm{b}}$ & $14.60^{\mathrm{c}}$ \\
\hline $\mathrm{C}$ & $1.24^{\mathrm{b}}$ & $7.35^{\mathrm{e}}$ & $18.92^{\mathrm{e}}$ \\
\hline \multicolumn{4}{|l|}{ Shoots } \\
\hline EO I & $8.46^{\mathrm{d}}$ & $4.02^{\mathrm{a}}$ & $8.25^{\mathrm{a}}$ \\
\hline EO II & $7.21^{\mathrm{c}}$ & $3.81^{\mathrm{a}}$ & $9.93^{b}$ \\
\hline DF I & $3.87^{\mathrm{a}}$ & $4.66^{\mathrm{bc}}$ & $7.98^{\mathrm{a}}$ \\
\hline DF II & $3.74^{\mathrm{a}}$ & $4.43^{\mathrm{b}}$ & $7.42^{\mathrm{a}}$ \\
\hline P I & $7.45^{\mathrm{c}}$ & $5.00^{\mathrm{c}}$ & $11.95^{\mathrm{c}}$ \\
\hline P II & $6.31^{\mathrm{b}}$ & $3.88^{\mathrm{a}}$ & $14.17^{\mathrm{e}}$ \\
\hline $\mathrm{C}$ & $7.11^{\mathrm{c}}$ & $6.32^{\mathrm{d}}$ & $13.10^{\mathrm{d}}$ \\
\hline \multicolumn{4}{|l|}{ Roots } \\
\hline EO I & $2.72^{\mathrm{c}}$ & $6.66^{\mathrm{c}}$ & $6.87^{\mathrm{a}}$ \\
\hline EO II & $1.02^{\mathrm{a}}$ & $6.54^{\mathrm{c}}$ & $7.43^{\mathrm{a}}$ \\
\hline DF I & $1.43^{\mathrm{b}}$ & $6.67^{\mathrm{c}}$ & - \\
\hline DF II & $2.51^{\mathrm{c}}$ & $4.05^{\mathrm{a}}$ & - \\
\hline P I & $5.09^{\mathrm{f}}$ & $4.87^{\mathrm{ab}}$ & $9.17^{\mathrm{a}}$ \\
\hline P II & $4.57^{\mathrm{e}}$ & $5.18^{\mathrm{ab}}$ & - \\
\hline $\mathrm{C}$ & $3.79^{\mathrm{d}}$ & $5.42^{\mathrm{b}}$ & $9.05^{\mathrm{a}}$ \\
\hline
\end{tabular}

* Means in columns for each organ of plant marked with the same letters do not differ significantly according to LSD test at $p<0.05$. Symbols as in Fig. 1
Table 4 The effect of petroleum-derived substances on content of selected heavy metals in Vicia faba L. $\left(\mathrm{mg} \mathrm{kg}^{-1}\right)$

\begin{tabular}{|c|c|c|c|c|c|c|}
\hline Details & $\mathrm{Cu}$ & $\mathrm{Mn}$ & $\mathrm{Ni}$ & $\mathrm{Pb}$ & $\mathrm{Zn}$ & $\mathrm{Cd}$ \\
\hline \multicolumn{7}{|l|}{ Leaves } \\
\hline EO I & $20.21^{\mathrm{a}^{*}}$ & $377.32^{\mathrm{a}}$ & $3.76^{\mathrm{bc}}$ & $17.89^{\mathrm{a}}$ & $226.18^{\mathrm{b}}$ & $1.94^{\mathrm{ab}}$ \\
\hline EO II & $19.78^{\mathrm{a}}$ & $474.22^{\mathrm{b}}$ & $3.84^{\mathrm{bc}}$ & $30.40^{\mathrm{ab}}$ & $223.93^{\mathrm{b}}$ & $1.80^{\mathrm{a}}$ \\
\hline DF I & $19.11^{\mathrm{a}}$ & $879.84^{\mathrm{e}}$ & $3.06^{\mathrm{ab}}$ & $42.73^{\mathrm{b}}$ & $225.44^{\mathrm{b}}$ & $2.37^{\mathrm{c}}$ \\
\hline DF II & $17.82^{\mathrm{a}}$ & $784.97^{\mathrm{d}}$ & $2.32^{\mathrm{a}}$ & $14.78^{\mathrm{a}}$ & $222.75^{\mathrm{b}}$ & $2.02^{\mathrm{ab}}$ \\
\hline P I & $20.63^{\mathrm{a}}$ & $317.69^{a}$ & $4.62^{c}$ & $12.87^{\mathrm{a}}$ & $201.80^{\mathrm{a}}$ & $2.13^{\mathrm{bc}}$ \\
\hline P II & $23.64^{\mathrm{b}}$ & $354.61^{\mathrm{a}}$ & $2.77^{\mathrm{a}}$ & $30.76^{\mathrm{ab}}$ & $214.94^{\mathrm{ab}}$ & $2.16^{\mathrm{bc}}$ \\
\hline $\mathrm{C}$ & $18.69^{\mathrm{a}}$ & $580.96^{\mathrm{c}}$ & $3.16^{\mathrm{ab}}$ & $9.91^{\mathrm{a}}$ & $257.95^{\mathrm{c}}$ & $3.17^{\mathrm{d}}$ \\
\hline \multicolumn{7}{|l|}{ Shoots } \\
\hline EO I & $12.87^{\mathrm{cd}}$ & $82.72^{\mathrm{b}}$ & $1.24^{\mathrm{a}}$ & $8.73^{\mathrm{a}}$ & $138.53^{\mathrm{a}}$ & $1.55^{\mathrm{a}}$ \\
\hline EO II & $10.00^{\mathrm{ab}}$ & $91.90^{\mathrm{b}}$ & $1.24^{\mathrm{a}}$ & $9.91^{\mathrm{ab}}$ & $148.47^{\mathrm{ab}}$ & $1.79^{\mathrm{a}}$ \\
\hline DF I & $9.18^{\mathrm{a}}$ & $132.83^{\mathrm{d}}$ & $1.20^{\mathrm{a}}$ & $6.88^{\mathrm{a}}$ & $152.20^{\mathrm{ab}}$ & $1.83^{\mathrm{a}}$ \\
\hline DF II & $11.12^{\mathrm{abc}}$ & $129.97^{\mathrm{d}}$ & $1.30^{\mathrm{a}}$ & $13.72^{\mathrm{b}}$ & $161.53^{\mathrm{b}}$ & $1.84^{\mathrm{a}}$ \\
\hline P I & $14.70^{\mathrm{de}}$ & $49.72^{\mathrm{a}}$ & $1.50^{\mathrm{a}}$ & $32.18^{\mathrm{c}}$ & $154.29^{\mathrm{ab}}$ & $1.99^{\mathrm{a}}$ \\
\hline P II & $16.12^{\mathrm{e}}$ & $56.56^{\mathrm{a}}$ & $1.39^{\mathrm{a}}$ & $34.73^{\mathrm{c}}$ & $167.72^{\mathrm{b}}$ & $1.89^{\mathrm{a}}$ \\
\hline $\mathrm{C}$ & $12.26^{\mathrm{bcd}}$ & $113.34^{\mathrm{c}}$ & $2.00^{\mathrm{b}}$ & $13.06^{\mathrm{b}}$ & $137.07^{\mathrm{a}}$ & $2.19^{\mathrm{a}}$ \\
\hline \multicolumn{7}{|l|}{ Roots } \\
\hline EO I & $39.33^{\mathrm{b}}$ & $481.37^{\mathrm{cd}}$ & $1.97^{\mathrm{bc}}$ & $20.53^{\mathrm{a}}$ & $272.78^{c}$ & $4.14^{\mathrm{b}}$ \\
\hline EO II & $38.63^{\mathrm{b}}$ & $583.72^{\mathrm{e}}$ & $1.61^{\mathrm{ab}}$ & $21.70^{\mathrm{ab}}$ & $265.64^{\mathrm{c}}$ & $3.86^{\mathrm{ab}}$ \\
\hline DF I & $37.31^{\mathrm{b}}$ & $558.11^{\mathrm{de}}$ & $1.41^{\mathrm{a}}$ & $23.20^{\mathrm{ab}}$ & $224.39^{\mathrm{b}}$ & $4.56^{\mathrm{b}}$ \\
\hline DF II & $29.16^{\mathrm{a}}$ & $427.90^{\mathrm{bc}}$ & $1.72^{\mathrm{ab}}$ & $20.84^{\mathrm{a}}$ & $166.78^{\mathrm{a}}$ & $3.16^{\mathrm{a}}$ \\
\hline P I & $27.20^{\mathrm{a}}$ & $200.69^{\mathrm{a}}$ & $2.39^{\mathrm{d}}$ & $23.77^{\mathrm{ab}}$ & $230.69^{\mathrm{b}}$ & $6.20^{\mathrm{c}}$ \\
\hline P II & $35.32^{\mathrm{b}}$ & $388.63^{\mathrm{b}}$ & $2.46^{\mathrm{d}}$ & $24.91^{\mathrm{ab}}$ & $262.75^{\mathrm{c}}$ & $4.46^{\mathrm{b}}$ \\
\hline $\mathrm{C}$ & $24.72^{\mathrm{a}}$ & $428.26^{\mathrm{bc}}$ & $2.35^{\mathrm{cd}}$ & $27.80^{\mathrm{b}}$ & $357.54^{\mathrm{d}}$ & $7.83^{\mathrm{d}}$ \\
\hline
\end{tabular}

*Means in columns for each organ of plant marked with the same letters do not differ significantly according to LSD test at $p<0.05$. Symbols as in Fig. 1
Table 5 Multiple regression equations $(p<0.05)$

\begin{tabular}{|c|c|c|}
\hline & & $R^{2}$ \\
\hline \multicolumn{2}{|c|}{ Life span $=9.03-0.36($ ps dose $)+0.84(\mathrm{Cd})-0.46(\mathrm{Zn})$} & \multirow[t]{2}{*}{0.892} \\
\hline$(0.15)$ & $(0.19)$ & \\
\hline \multicolumn{2}{|c|}{ Fecundity $=32.65-0.36(\mathrm{ps}$ dose $)-0.46(\mathrm{~S})-0.45(\mathrm{Mn})+0.428(\mathrm{Cd})$} & \multirow[t]{2}{*}{0.978} \\
\hline$(8.98)$ & $(0.07)$ & \\
\hline \multicolumn{2}{|c|}{ Intrinsic growth rate $=-0.23-0.54(\mathrm{ps}$ dose $)+0.757(\mathrm{~N})+1.00(\mathrm{~K})+0.585(\mathrm{Ca})$} & \multirow[t]{2}{*}{0.921} \\
\hline$(0.09)$ & $(0.15)$ & \\
\hline
\end{tabular}

Principal component analysis of element levels in $V$. faba organs, and soil contamination with PDSs showed that the elements correlated with the 1 st ordination axis accounting for more than $93 \%$ of variation of the analyzed samples (Fig. 4). K and $\mathrm{Zn}$ contents were the most correlated with the 1st ordination axis. The highest concentrations of $\mathrm{Ca}$, $\mathrm{Ni}$, and $\mathrm{Mn}$ were found in plants exposed to diesel fuel and engine oil in both doses and petrol at the dose of $9 \mathrm{~g} \mathrm{~kg}^{-1}$, as well as in leaves from control plants. In the roots the highest content of $\mathrm{Pb}$ and $\mathrm{Cd}$ were found in plants planted in soil contaminated with diesel fuel and engine oil. Also Fe and $\mathrm{Cu}$ levels were the highest in plants from the soil contaminated with diesel fuel at the dose of $9 \mathrm{~g} \mathrm{~kg}^{-1}$ and engine oil at the dose of $18 \mathrm{~g} \mathrm{~kg}^{-1}$. The lowest content of the investigated elements except $\mathrm{K}$ was found in shoots of broad been. 
Fig. 4 Principal component analysis of element levels in $V$. faba in organs, and soil contamination with petroleumderived substances. Symbols as in Fig. 1. $L$ leaves, $S$ shoots, $R$ roots

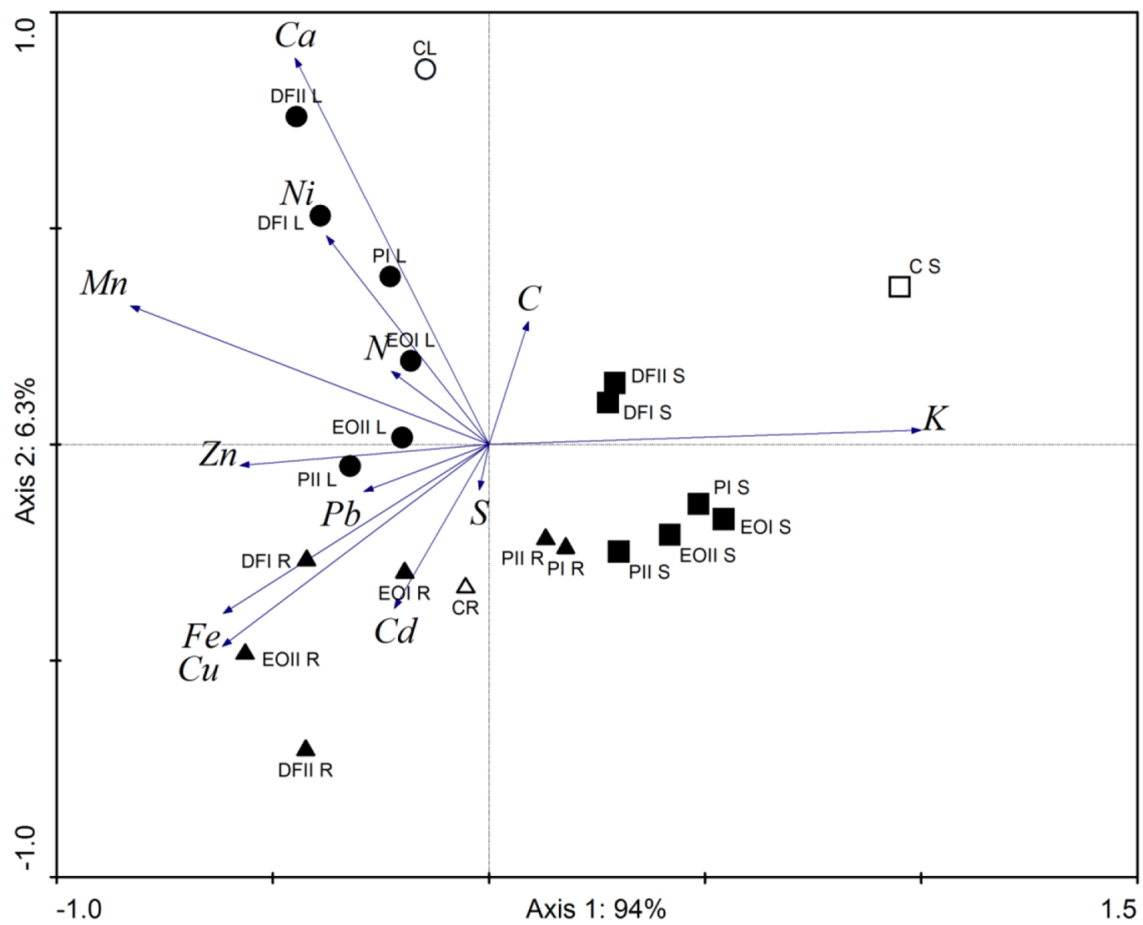

\section{Discussion}

In conducted experiment only the parthenogenetic part of the life cycle of $A$. fabae was investigated. The effects of moving to other host plants (possibly uncontaminated) and of sexual reproduction were not accounted. Therefore, the experiment does not provide a complete response on the effect of PDSs on A. fabae biology. However, given that on herbaceous plants can develop to 10 asexual generations (which comprises about $80 \%$ of full life cycle), this may involve significant implications both for the whole pest population in a given area, and for its natural enemies.

The average fecundity of wingless females of A. fabae on broad bean in uncontaminated conditions ranges from 15.3 to 59.2 larvae and depends on the cultivars of broad bean and the generation of pests. It usually declines in subsequent generations, what is the result of changes in the host plant, associated with its growth and ageing (Cichocka et al. 2002). Aphid life span is about 23 days (also usually decreases across generation) and intrinsic growth rate amounts to 0.345 (Douglas 1997). In our experiment analysed life history traits were at a similar level, while population intrinsic growth rate was lower and ranged $0.156-0.264$ depending on generation. All PDSs used in this experiment had an adverse impact on the life cycle traits of black bean aphid, causing its fecundity to decline, shortening its life span, prolonging the pre-reproductive period, and usually causing the population intrinsic growth rate to drop. Available scientific literature lacks information concerning the effect of soil contamination with PDSs on the life cycle traits of herbivores. Causes of the noted changes in black bean aphid life history can be partly deduced by confronting the obtained results with the changes of chemical composition in the host plant ensuing from soil contamination, as well as with the results provided by studies concerning other types of soil contamination, e.g., with heavy metals, especially in view of the known fact that PDSs cause heavy metal levels to increase in soil (Okonokhua et al. 2007; Ujowundu et al. 2011; Wyszkowski and Sivitskaya 2012).

Changes in life history traits of aphids caused by the presence of PDSs in the soil may result from impairment of the host plant trophic value. PDSs impede the growth and development of crops and alter their macro- and microcomponent contents. All PDSs used in the performed experiment had a negative impact on the growth of broad bean plants and this impact usually intensified in a dosedependent manner. Many authors accentuate the harmful effect of PDSs on crop growth and development (Liste and Felgentreu 2006; Njoku et al. 2008; Njoku et al. 2012; Osuagwu et al. 2013; Lopes and Piedade 2014; Rusin et al. 2015). The adverse action of PDSs on cultivated plants may result from the lowered content of nutrients available to plants consequent upon the presence of these contaminants in soil. Disruption in photosynthesis and decreased chlorophyll levels may cause plant growth inhibition or death (Odjegba and Atebe 2007). These substances increase soil density, which causes soil pores to clog and consequently alters the physical, chemical and biological properties of soil and disturbs water and nutrient uptake by plants. PDSs 
may also block the molecular transport in plant cells, which may contribute to the limited development of vegetative and generative organs (Osuagwu et al. 2013). Aqueel et al. (2014) confirmed that plant quality can affect the feeding of aphids and other consumers with higher trophic level. On high quality plants the aphids produced most offspring and were characterized by a higher population intrinsic growth rate (Stadler et al. 2002). Bad condition of plants, demonstrated by a significant growth restriction, caused by the presence of heavy metals in the soil, reduces fecundity of A. fabae and results in a shortening of its life span (Gospodarek 2012).

Aphids feed by piercing the phloem of their food plant and are very sensitive to changes in plant quality (Omacini et al. 2001). Quality of plants is largely determined by the content of macro- and micronutrients which directly affect potential and achieved herbivore fecundity (Awmack and Leather 2002). PDSs used in this experiment most often caused carbon and sulphur levels to rise in plant leaves and shoots, but both diesel fuel and engine oil contributed to a drop in leaf nitrogen level. Rusin et al. (2015) also showed that PDSs reduced nitrogen level in the leaves of broad bean, but some of them caused a reduction in sulphur and carbon content, which only partially corresponds to results of the present experiment. The discrepancies may be due to different doses of pollutant used in the two experiments. In soils contaminated with PDSs, the nitrogen-to-carbon ratio is distorted by the presence of hydrocarbons. This contributes to many nitrogen reactions being curbed in soil and also lowers the intensity of ammonification and nitrification processes (Adam and Duncan 2003). PDSs provide an increased carbon content in soil, which results from their structure (they contain aliphatic hydrocarbons, cycloalkanes, olefins and arenes) (Riffaldi et al. 2006; Wyszkowski and Sivitskaya 2012). Moubasher et al. (2015) showed that petroleum-derived hydrocarbons usually caused no significant change in the sulphur content of Bassia scoparia (L.) roots and shoots. In our experiment, PDSs caused a significant increase in the content of this nutrient in broad bean leaves and shoots. Again, the disparities may stem from the different species of test plant and a different dose of substances applied in the two experiments. The impact of PDSs on the content of calcium, magnesium, potassium and iron in plants was diverse and depended on the analysed component, dose and type of contaminant and part of plants. PDSs can have various effects on plant $\mathrm{Ca}, \mathrm{Mg}, \mathrm{K}$ and $\mathrm{Fe}$ content, depending on the species, doses and the part of the plant (Wyszkowski and Ziółkowska 2009a, b). An optimum value of $\mathrm{K} /(\mathrm{Ca}+\mathrm{Mg})$ ratio for plants to grow and develop should range within 1.6/1-2.1/1 (Matraszek et al. 2015). The effect of PDSs on the value of the said indicator was varied and depended on the substance applied, its dose, as well as plant part examined. The $\mathrm{Ca} / \mathrm{Mg}$ value in our experiment ranged within 3.67-7.35. PDSs usually acted towards a decrease in the value of this indicator in leaves and shoots. The N/S ratio informs of the degree to which plants are supplied with sulphur and its value in vegetative plant organs should range around 15/1 (Jamal et al. 2010). In the conducted experiment, the value of this indicator was most often slightly below its optimum, and it was also noted that PDSs usually decreased it significantly in broad bean leaves and shoots. These changes in nutrients content and nutrients ratio may result in a deteriorated fodder quality for pests (Nadgórska-Socha et al. 2005), which can explain the negative impact of PDSs on life history traits of the $A$. fabae. Numerous authors indicate that the increasing nitrogen content in host plants entails enhanced infestation by aphids (Honêk and Martinkova 2002; Davies et al. 2004; Naluyange et al. 2014). In this experiment, engine oil and diesel fuel caused a significant decrease in the nitrogen content of broad bean leaves when applied at both doses, which may have conducted to life span shortening and fecundity reduction in all three black bean aphid generations. Jansson and Ekbom (2002) also found that higher content of $\mathrm{N}$ and $\mathrm{K}$ in petunia plants accelerates the development of Macrosiphum euphorbiae and has a positive effect on its life span. In our experiment PDSs often decreased the content of potassium in shoots and leaves of broad bean which may adversely affect life history traits of A. fabae. Moreover, PDSs usually contributed to a reduction in calcium content. Changes in the content of this macrocomponent may also cause disturbances in the occurrence of the piercing-sucking herbivores (Saqdej and Sądej 2001). Available scientific literature lacks information concerning the effect of other analysed nutrients content on life history traits of aphids.

The composition of PDSs contains heavy metals, polycyclic aromatic hydrocarbons (PAHs) and other chemical admixtures, which are toxic to living organisms. Therefore, the adverse effect of PDSs on life history traits of aphids may also result from the transfer of harmful substances from the soil through plants to the aphids. Merrington et al. (2001) found that aphids accumulate more toxic metals in the bodies than their host plants in the tissues. Numerous authors underscore that soil contamination with heavy metals may strongly affect the life history traits of aphids (Gospodarek 2005, 2012; Görür 2007, 2009). Davies et al. (1998) found that black bean aphid larvae reach sexual maturity after $5.85 \pm 0.35$ days under laboratory conditions, whereas Gospodarek (2012) demonstrated that this period may extend to 12.2 days in conditions of soil contamination with heavy metals. The PDSs in the present experiment also caused elongation of the pre-reproductive period that reached up to 12.8 days, while the control values ranged between 9.0 and 11.3 days. Soil pollution with heavy metals such as $\mathrm{Zn}$ and Ni used separately reduces fecundity and life 
span of A. fabae, 2-3 times and by approx. 30\% respectively (Gospodarek 2012). In our experiment fecundity of aphids under the influence of lower PDSs doses decreased 2-10 times, while in the case of higher doses-10-20 times and life span decreased by approx. $30-50 \%$ on average. Nevertheless, it should be noted that in conducted by mentioned author studies, the content of $\mathrm{Zn}$ and $\mathrm{Ni}$ in broad bean tissues was several dozen times higher than in our experiment. In mentioned experiment (Gospodarek 2012) an increase in $\mathrm{Pb}, \mathrm{Cd}$ and $\mathrm{Cu}$ content in broad bean tissues did not contribute to a reduction in fecundity and life span of A. fabae. In our experiment heavy metals content in leaves and shoots of broad bean plants was varied depending on the type of pollutants, its dose and type of metal.

PDSs alter heavy metal levels in soil, which may also indirectly affect these levels in plant organs (SantosEcheandia et al. 2008). Some authors have shown that PDSs cause soil levels of cadmium, lead, copper and manganese to rise (Okonokhua et al. 2007; Ujowundu et al. 2011; Wyszkowski and Sivitskaya 2012). It can explain the elevated content of $\mathrm{Cu}$ in broad bean roots in the present experiment. However, all PDSs caused a drop in cadmium content of broad bean leaves and roots. Rusin et al. (2015) also demonstrated that spent engine oil and petrol contribute to a significant reduction of cadmium levels in broad bean leaves. Similar findings were made by Nwaichi et al. (2014), who showed that PDSs cause the level of this metal to decrease in the leaves of Vernonia amygdelina i Talinum triangulare. The authors also showed that PDSs increased lead levels in plant leaves, which was confirmed in the study by Rusin et al. (2015). In the present experiment, only diesel fuel at the dose of $9 \mathrm{~g} \mathrm{~kg}^{-1}$ induced lead level to rise in broad bean leaves. Petrol also caused the content of this metal to grow in shoots, though shoot and root lead contents were observed to fall as a result of engine oil and diesel fuel present in soil.

Available scientific literature provides scarce information about the transfer of PAHs from contaminated soil to plants. Gao and Zhu (2004) found that accumulation of phenanthrene and pyrene in plants was elevated with the increase of their soil concentrations. This indicates that adverse effect of PDSs on life history traits of A. fabae may result not only from the transfer of heavy metals but also other harmful compounds of PDSs such as PAHs.

The magnitude of changes in the content of macro and micronutrients as well as heavy metals content (when we consider them separately) was not so great to make conclusion that these changes are the main causes of adverse effect of PDSs on life history traits of A. fabae. This suggests the possibility of a synergistic effect of impairment of the plant trophic value and the transfer of toxic substances in this soil-plant-aphids interaction.

\section{Conclusions}

1. All PDSs used had an adverse effect on life history traits of black bean aphid, causing a decline in its fecundity, shortening its mean life span, extending the pre-reproductive period, and most often lowering the population intrinsic growth rate.

2. The adverse effect of PDSs on life history traits of aphids may be associated with synergistic influence of impairment of the host plant trophic value and the transfer of toxic substances from the soil through plants to the aphids. PDSs produced a negative effect on the growth of broad bean plants and modified nutrients content. These substances most frequently caused an increase in carbon and sulphur levels in plant leaves and shoots, though both diesel fuel and engine oil caused a decrease in nitrogen level in broad bean leaves. All substances applied caused a decrease in iron and potassium levels in plant shoots, as well as most frequently a decrease of calcium level in leaves. Diesel fuel caused an increase in manganese levels in broad bean leaves and shoots, engine oil-an increase in copper levels in roots, while petrol-an increase in lead levels in plant shoots.

3. Obtained results indicate that soil contamination with PDSs entails far-reaching changes not only in organisms directly exposed to these pollutants (plants), but also indirectly in herbivores (aphids) and consequently provides information about potential negative effects on further links of the food chain, i.e., for predators and parasitoids.

Acknowledgements The work was financed from designated subsidy to conduct research, development work and related tasks, contributing to the development of young scientists and University of Agriculture phD students financed under competition procedure in 2015. No topic 4172.

\section{Compliance with ethical standards}

Conflict of interest The authors declare that they have no conflict of interest.

Open Access This article is distributed under the terms of the Creative Commons Attribution 4.0 International License (http:// creativecommons.org/licenses/by/4.0/), which permits unrestricted use, distribution, and reproduction in any medium, provided you give appropriate credit to the original author(s) and the source, provide a link to the Creative Commons license, and indicate if changes were made. 


\section{References}

Achuba FI (2006) The effects of sublethal concentrations of crude oil on growth and metabolism of cowpea (Vigna unguiculata) seedlings. Environmentalist 26:17-20

Adam G, Duncan H (2003) The effect of diesel fuel on common vetch (Vicia sativa L.) plants. Environ Geochem Hlth 25(1):123-130.

Adenipekun CO, Oyetunji OJ, Kassim LS (2008) Effect of spent engine oil on the growth parameters and chlorophyll content of Corchorus olitorius Linn. Environmentalist 28(4):446-450

Agbogidi OM, Eruotor PG, Akparobi SO, Nnaji GU (2007) Evaluation of crude oil contaminated soil on the mineral nutrient elements of maize (Zea mays L.). J Agron 6:188-193

Agbogidi OM, Eshegbeyi OF (2006) Performance of Dacryodes edulis (Don. G. Lam H. J.) seeds and seedlings in a crude oil contaminated soil. J Sustain Forest 22(3-4):1-13

Aqueel MA, Collins CM, Raza AB, Ahmad S, Tariq M, Leather SR (2014) Effect of plant nutrition on aphid size, prey consumption, and life history characteristics of green lacewing. Insect Sci 21 (1):74-82

Awmack CS, Leather SR (2002) Host plant quality and fecundity in herbivorous insects. Annu Rev Entomol 47:817-844

Azcue J, Murdoch A (1994) Comparison of different washing, ashing, and digestion methods for the analysis of trace elements in vegetation. Int J Environ Chem 57:151-162

Baran S, Bielińska EJ, Oleszczuk P (2004) Enzimatic activity in an airfield soil polluted with polycyclic aromatic hydrocarbons. Geoderma 118(3-4):221-232

Besalatpour A, Khoshgoftarmanesh AH, Hajabbasi MA, Afyuni M (2008) Germination and growth of selected plants in a petroleum contaminated calcareous coil. Soil Sediment Contam 17 (6):665-676

Caravaca F, Rodán A (2003) Assessing changes in physical and biological properties in soil contaminated by oil sludges under semiarid Mediterranean conditions. Geoderma 117:53-61

Cichocka E, Leszczyński B, Ciepiela AP, Goszczyński W (2002) Response of Aphis fabae Scop. to different broad bean cultivars. EJPAU Horticulture 5(2), http://www.ejpau.media.pl

Davies FT Jr, Chunajiu H, Chau A, Heinz KM, Cartmill AD (2004) Fertility affects susceptibility of chrysanthemum to cotton aphids: influence on plant growth, phothosynthesis, ethylene evolution, and herbivore abundance. J Amer Soc Hort Sci 129(3):344-353

Davies MT, Port GR, Davison AW (1998) Effects of dietary and gaseous fluoride on the aphid Aphis fabae. Environ Pollut 99 (3):405-409

Douglas AE (1997) Provenance, experience and plant utilisation by the polyphagous aphid, Aphis fabae. Entomol Exp Appl 83:161-170

Gao Y, Zhu L (2004) Plant uptake, accumulation and translocation of phenanthrene and pyrene in soils. Chemosphere 55(9):1169-1178

Gbadebo AM, Adenuga MD (2012) Effect of crude oil on the emergence and growth of cowpea in two contrasting soil types from Abeokuta, Southwestern Nigeria. Asian J Appl Sci 5:232-239

Görür G (2007) Effects of host plant contaminated with heavy metals on the life history traits of aphids (Brevicoryne brassicae L.). Pol J Ecol 55(1):113-120

Görür G (2009) Zinc and cadmium accumulation in cabbage aphid (Brevicoryne brassicae) host plants and developmental instability. Insect Sci 16(1):65-71

Gospodarek J (2005) The effect of zinc on development of Aphis fabae Scop. Post Ochr Roś/ Progr Plant Protect 45(2):680-682. (in Polish)

Gospodarek J (2012) Occurrence of black bean aphid (Aphis fabae Scop.) and its natural predators on broad bean under the conditions of soil pollution with heavy metals. Zesz Nauk UR w Krakowie 480 (357), ser. Rozprawy:40-43 (in Polish)
Grant WF, Lee HG, Logan DM, Salamone MF (1992) The use of Tradescantia and Vicia faba bioassays for the in situ detection of mutagens in an aquatic environment. Mutat Res 270:53-64

Green ID, Jeffries C, Diaz A, Tibbett M (2006) Contrasting behaviour of cadmium and zinc in a soil-plant-arthropod system. Chemosphere 64:1115-1121

Harrington R, Stork NE (1995) Insect in a changing Environment. In: Proceedings of the 17th Symposium of the Royal Entomological Society. Academic Press London 535.

Honêk A, Martinkova Z (2002) Factors of between- and within-plant distribution of Metopolophium dirhodum (Hom. Aphididae) on small grain cereals. J Appl Entomol 126(7/8):378-383

Iturbe R, Flores C, Castro A, Torres LG (2007) Sub-soil contamination due to oil spills in zones surrounding oil pipeline-pump stations and oil pipeline right-of-ways in Southwest-Mexico. Environ Monit Assess 133(1-3):387-398

Jamal A, Moon YS, Abdin MZ (2010) Sulphur-a general overview and interaction with nitrogen. Aust J Crop Sci 4(7):523-529

Jansson J, Ekbom B (2002) The effect of different plant nutrient regimes on the aphid Macrosiphum euphorbiae growing on petunia. Entomol Exp Appl 104:109-116

Kafel A, Nadgórska-Socha A, Gospodarek J, Babczyńska A, Skowronek M, Kandziora M, Rozpedek K (2010) The effects of Aphis fabae infestation on the antioxidant response and heavy metal content in field grown Philadelphus coronarius plants. Sci Total Environ 408:1111-1119

Kanaya N, Gill BS, Grover IS, Murin A, Osiecka R, Sandhu SS, Anderson HC (1994) Vicia faba chromosomal aberation assay. Mutat Res 310:231-247

Lawrence I (2013) Effect of crude oil spillage on soil physicochemical properties in Ugborodo community. IJMER 3 (6):3336-3342

Lipok J (2009) Dual action of phosphonate herbicides in plants affected by herbivore- Model study on black bean aphid Aphis fabae rearing on broad bean Vicia faba plants. Ecotox Environ Saf 72:1701-1706

Liste H, Felgentreu D (2006) Crop growth, culturable bacteria and degradation of petrol hydrocarbons (PHCs) in a long-term contaminated field soil. Appl Soil Ecol 31:43-52

Lopes A, Piedade MTF (2014) Experimental study on the survival of the water hyacinth (Eichhornia crassipes (Mart.) Solms-Pontederiaceae) under different oil doses and times of exposure. Environ Sci Pollut Res 21:13503-13511

Malallah G, Afzal M, Gulshan S, Abraham D, Kurian M, Dhami MSI (1996) Vicia faba as a bioindicator of oil pollution. Environ Pollut 92(2):213-217

Matraszek R, Hawrylak-Nowak B, Chwil S, Chwil M (2015) Macronutrient composition of nickel-treated wheat under different sulfur concentrations in the nutrient solution. Environ Sci Pollut Res Int 23:1-13

Merrington G, Miller D, McLaughlin MJ, Keller MA (2001) Trophic barriers to fertilizer $\mathrm{Cd}$ bioaccumulation through the food chain: a case study using a plant-insect predator pathway. Arch Environ Contam Toxicol 41:151-156

Merrington G, Winder L, Green I (1997a) The uptake of cadmium and zinc by the bird-cherry oat aphid Rhopalosiphium padi (Homoptera: Aphididae) feeding on wheat grown on sewage sludge amended agricultural soil. Environ Pollut 96:111-114

Merrington G, Winder L, Green I (1997b) The bioavailability of Cd and $\mathrm{Zn}$ from soils amended with sewage sludge to winter wheat and subsequently to the grain aphid Sitobion avenae. Sci Total Environ 205:245-254

Moubasher HA, Hegazy AK, Mohamed NH, Moustafa YM, Kabiel HF, Hamad AA (2015) Phytoremediation of soils polluted with crude petroleum oil using Bassia scoparia and its associated rhizosphere microorganisms. Int Biodeter Biodegr 98:113-120 
Nadgórska-Socha A, Gospodarek J, Jaworska M, Ciepał R (2005) Content of assimilation pigments, phosphorus and protein in broad bean Vicia faba L. ssp. maior grown in heavy metals contaminated soils. Ecol Chem Eng 12(4):421-426

Nadgórska-Socha A, Kafel A, Kandziora-Ciupa M, Gospodarek J, Zawisza-Raszka A (2013) Accumulation of heavy metals and antioxidant responses in Vicia faba plants grown on monometallic contaminated soil. Environ Sci Pollut R 20 (2):1124-1134

Naluyange V, Ochieno DMW, Maingi JM, Ombori O, Mukaminego D, Amoding A, Odendo M, Okoth SA, Shivoga WA, Muoma JVO (2014) Compatibility of Rhizobium inoculant and water hyacinth compost formulations in Rosecoco bean and consequences on Aphis fabae and Colletotrichum lindemuthianum infestations. Appl Soil Ecol 76:68-77

Njoku KL, Akinola MO, Busari TO (2012) Effect of time of application of spent oil on the growth and performance of maize (Zea mays). AJEST 6(1):67-71

Njoku KL, Akinola MO, Oboh BO (2008) Growth and performance of Glycine $\max$ L. (Merrill) grown in crude oil contaminated soil augmented with cow dung. Life Sci J 5(3):89-93

Nwaichi EO, Wegwu MO, Nwosu UL (2014) Distribution of selected carcinogenic hydrocarbon and heavy metals in an oil-polluted agriculture zone. Environmental Monitoring and Assessment 186 (12):8697-8706

Odjegba VJ, Atebe JO (2007) The effect of used engine oil on carbohydrate, mineral content and nitrate reductase activity of leafy vegetable (Amaranthus hybridus L.). J Appl Sci Environ Manage 11(2):191-196

Okonokhua BO, Ikhajiagbe B, Anoliefo GO, Emende TO (2007) The effects of spent engine oil on soil properties and growth of maize (Zea mays L.). J Appl Sci Environ Manage 11(3):147-152

Omacini M, Chaneton EJ, Ghersa CM, Müller CB (2001) Symbiotic fungal endophytes control insect host-parasite interaction webs. Nature 409(6816):78-81

Onweremadu EU, Duruigbo CI (2007) Assessment of cadmium concentration of crude oil polluted arable soils. Int J Environ Sci Tech 4:409-412

Osuagwu AN, Okigbo AU, Ekpo IA, Chukwurah PN, Agbor RB (2013) Effect of crude oil pollution on growth parameters, chlorophyll content and bulbils yield in air potato (Dioscorea bulbifera L.). Int J Appl Sci Technol 3(4):37-42

Percy K, Awmack C, Lindroth R, Kubiske M, Kopper B, Isebrands J, Pregitzer K, Hendrey G, Dickson R, Zak D, Oksanen E, Sober J, Harrington R, Karnosky D (2002) Altered performance of forest pests under atmospheres enriched by $\mathrm{CO}_{2}$ and $\mathrm{O}_{3}$. Nature 420:403-407

Riffaldi R, Levi-Minzi R, Cardelli R, Palumbo S, Saviozzi A (2006) Soil biological activities in monitoring the bioremediation of diesel oil-contaminated soil. Water Air Soil Pollut 170(1-4):3-15

Rusin M, Gospodarek J, Nadgórska-Socha A (2015) The effect of petroleum-derived substances on the growth and chemical composition of Vicia faba L. Pol J Environ Stud 24 (5):2157-2166
Sandrock C, Razmjou J, Vorburger C (2011) Climate effects on life cycle variation and population genetic architecture of the black bean aphid, Aphis fabae. Mol Ecol 20(19):4165-4181

Santos-Echeandia J, Prego R, Cobelo-Garcia A (2008) Influence of the heavy fuel spill from the Prestige tanker wreckage in the overlying seawater column levels of copper, nickel and vanadium (NE Atlantic ocean). J Mar Syst 72:350-357

Sądej W, Sądej W (2001) Effect of different fertilization dosages on a population of black aphids (Aphis fabae Scop.) on horse bean plants. Prog Plant Prot 41(2):555-558

Shirdam R, Zand AD, Bidhendi GN, Mehrdadi N (2008) Phytoremediation of hydrocarbon-contaminated soils with emphasis on the effect of petroleum hydrocarbons on the growth of plant species. Phytoprotection 89(1):21-29

Shukry WM, Al-Hawas GHS, Al-Moaik RMS, El-Bendary MA (2013) Effect of petroleum crude oil on mineral nutrient elements and soil properties of jojoba plant (Simmondsia chinensis). Acta Botanica Hungarica 55(1-2):117-133

Stadler B, Dixon AFG, Kindlmann P (2002) Relative fitness of aphids: effects of plant quality and ants. Ecol Lett 5(2):216-222

Ter Braak CJF, Šmilauer P (2002) CANOCO Reference manual and user's guide to Canoco for Windows: software for canonical community ordination (version 4.5). Microcomputer Power, Ithaca, NY

Ujowundu CO, Kalu FN, Nwaoguikpe RN, Kalu OI, Ihejirika CE, Nwosunjoku EC, Okechukwu RI (2011) Biochemical and physical characterization of diesel petroleum contaminated soil in southeastern Nigeria. Res J Chem Sci 1(8):57-62

Winder L, Merrington G, Green I (1999) The tri-trophic transfer of Zn from the agricultural use of sewage sludge. Sci Total Environ 229:3-81

Wyatt IJ, White PF (1977) Simple estimation of intrinsic increase rates for aphids and tetranychid mites. J Appl Ecol 14:757-766

Wyszkowska J, Kucharski J, Wałdowska E (2002) The influence of diesel oil contamination on soil enzymes activity. Rostl Vyrob 48 (2):58-62

Wyszkowski M, Sivitskaya V (2012) Changes in the content of organic carbon and available forms of macronutrients in soil under the influence of soil contamination with fuel oil and application of different substances. J Elem 17(1):139-148

Wyszkowski M, Wyszkowska J (2005) Effect of enzymatic activity of diesel oil contaminated soil on the chemical composition of oat (Avena sativa L.) and maize (Zea mays L.). Plant Soil Environ 51 (8):360-367

Wyszkowski M, Ziółkowska A (2008) Effect of petrol and diesel oil on content of organic carbon and mineral components in soil. Am-Eurasian J Sustain Agric 2(1):54-60

Wyszkowski M, Ziółkowska A (2009a) ) Effect of compost, bentonite and calcium oxide on concent of some macroelrments in plants from soil contaminated by petrol and diesel oil. J Elementol 14 (2):405-418

Wyszkowski M, Ziółkowska A (2009b) Role of compost, bentonite and calcium oxide in restricting the effect of soil contamination with petrol and diesel oil on plants. Chemosphere 74:860-865 